\title{
Predicting potential to benefit from an iron intervention: a randomized controlled trial of double-fortified salt in female Indian tea pluckers
}

\author{
Julie EH Nevins ${ }^{1, *}$, Sudha Venkatramanan ${ }^{1,2}$, Saurabh Mehta ${ }^{1}$ and Jere D Haas ${ }^{1}$ \\ 'Division of Nutritional Sciences, Cornell University, Savage Hall, 244 Garden Avenue, Ithaca, NY, 14853, USA: \\ ${ }^{2}$ Department of Dietetics and Human Nutrition, McGill University, Ste Anne de Bellevue, Quebec, Canada
}

Submitted 16 November 2018: Final revision received 2 April 2019: Accepted 17 April 2019: First published online 25 July 2019

\begin{abstract}
Objective: The present study examines characteristics of those who benefited from a dietary Fe intervention comprised of salt double-fortified with iodine and Fe (DFS).

Design: Data from a randomized controlled trial were analysed to identify predictors of improved Fe status and resolution of Fe deficiency (serum ferritin $(\mathrm{sFt})<12 \mu \mathrm{g} / \mathrm{l})$ and low body Fe (body Fe $(\mathrm{BI})<0.0 \mathrm{mg} / \mathrm{kg}$ ) using non-parametric estimations and binomial regression models.

Setting: A tea estate in West Bengal, India.

Participants: Female tea pluckers, aged 18-55 years.

Results: Consuming DFS significantly $(P=0 \cdot 01)$ predicted resolution of Fe deficiency (relative risk $(\mathrm{RR})=2 \cdot 31)$ and of low $\mathrm{BI}(\mathrm{RR}=2 \cdot 78)$ compared with consuming iodized salt. Baseline sFt $(\beta=-0.32$ (se 0.03), $P<0.001)$ and treatment group $(\beta=0.13$ (sE 0.03), $P<0.001)$ significantly predicted change in $\mathrm{sFt}$. The interaction of baseline BI with treatment group $(\beta=-0.11$ (SE 0.06), $P=0.08$ ) predicted the change in BI. DFS did not significantly predict change in $\mathrm{Hb}$ and marginally predicted resolution of anaemia $(\mathrm{Hb}<120 \mathrm{~g} / \mathrm{l})$.

Conclusions: Baseline Fe status, as assessed by sFt and BI, and consumption of DFS predict change in Fe status and resolution of Fe deficiency and low BI. Anaemia prevalence and $\mathrm{Hb}$ level, although simple and inexpensive to measure, may not be adequate to predict resolution of Fe deficiency in response to an intervention of DFS in similar populations with high prevalence of Fe deficiency and multiple nutritional causes of anaemia. These findings will guide appropriate targeting of future interventions.
\end{abstract}

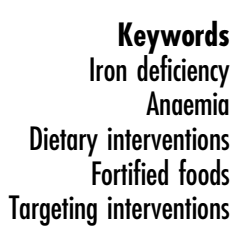

Keywords Anaemia Fortified foods Targeting interventions
Fe deficiency is a highly prevalent public health concern, affecting more than one-third of the world's population ${ }^{(1)}$. Functional consequences of Fe deficiency include anaemia and reductions in physical work capacity ${ }^{(2,3)}$, immune function $^{(4)}$ and cognitive performance ${ }^{(5,6)}$, as well as increased risk of depression ${ }^{(7)}$. These outcomes may be long-lasting and can occur before the development of overt anaemia, defined for women as $\mathrm{Hb}<120 \mathrm{~g} / \mathrm{l}^{(8)}$.

Women of reproductive age are at heightened risk of $\mathrm{Fe}$ deficiency, particularly in low-income countries ${ }^{(9)}$ where diets are low in Fe-rich foods and high in plant foods that can inhibit Fe absorption ${ }^{(7,10)}$. Fe supplementation is an efficacious method for ameliorating Fe deficiency, but financial and physical barriers often preclude its use in low-resource settings ${ }^{(11)}$. Widespread Fe supplementation also increases the risk that Fe-replete individuals will consume too much Fe, which could exacerbate morbidities from infections, notably malaria, hookworm and schistosomiasis $^{(12,13)}$.

Fortifying ubiquitous foods has resulted in large-scale decreases in other micronutrient deficiencies; folatefortified flour and vitamin D-fortified milk are two wellknown examples ${ }^{(14-17)}$. Salt iodization has reduced iodine deficiency to $<11 \%$ in the Americas, which has greater iodized salt consumption compared with Europe, where iodized salt consumption is low and $>50 \%$ prevalence of iodine deficiency has been reported ${ }^{(18)}$. Sustained salt iodization is expected to reduce goitre prevalence to 
$<5 \%{ }^{(18)}$, which by WHO estimates would eliminate iodine deficiency as a significant public health problem. Salt is a potentially successful fortification vehicle for delivering additional micronutrients, in part, because it is consumed daily by most of the world, is produced in many nutritionally at-risk areas and can be fortified using low-cost technology $^{(18-23)}$.

Previous research has demonstrated the efficacy of consuming salt double-fortified with iodine and Fe (DFS) to improve both iodine and Fe status in children ${ }^{(19,22,23)}$ as well as $\mathrm{Fe}$ status in women of reproductive age ${ }^{(24)}$. Although these well-designed randomized controlled trials provide evidence for a causal relationship between consumption of DFS and improved Fe status, little work has been done to examine the magnitude of impact and the potential effectiveness of programmes to reduce Fe deficiency with widespread DFS distribution ${ }^{(22,23,25-27)}$. To maximize the success of such programmes, there must first be evidence from efficacy trials of the behavioural and biological mechanisms through which the intervention results in an outcome of interest ${ }^{(25,26,28,29)}$. Inherently, randomized controlled efficacy trials can provide only limited information about generalizability, but are often useful to identify predictors of potential to benefit which aid in targeting populations for future interventions ${ }^{(30)}$.

The present analyses examine characteristics of those who benefited from an Fe intervention of DFS among female tea pluckers in West Bengal, India. Benefit is assessed with three methods: both as the absolute (i) and relative (ii) improvements in Fe biomarkers as well as the resolution of Fe deficiency (iii) over a 10-month intervention. The results presented here are of particular interest given the high economic and public health burdens of Fe deficiency and anaemia and the need to efficiently and effectively target DFS interventions to address these burdens.

\section{Study population and methods}

\section{Study site and participants}

Details of the study population and efficacy study are described in Haas et al. ${ }^{(24)}$. Briefly, participants were female tea pluckers (aged 18-55 years) who lived and worked on the Panighatta Tea Estate in West Bengal, India. Women were not eligible to participate if they were pregnant, had $\mathrm{Hb}$ concentration $<80 \mathrm{~g} / \mathrm{l}$ or $>150 \mathrm{~g} / \mathrm{l}$, were not residents of Panighatta or were not employed full-time on the tea estate. The population included two ethnic groups: the Nepali, whose ancestors emigrated from Nepal, and the Adivasi, an indigenous people considered to be of lower social and socio-economic status than the Nepali.

\section{Intervention}

Eligible women ( $n$ 248) were enrolled between July and September 2010, and were randomly assigned to receive salt fortified with potassium iodate $50 \mu \mathrm{g} / \mathrm{g}$ (IS) or salt doublefortified with potassium iodate $50 \mu \mathrm{g} / \mathrm{g}$ and $\mathrm{Fe} 1000 \mu \mathrm{g} / \mathrm{g}$ as encapsulated ferrous fumarate (DFS) for seven to ten months. All other types of commercially available salt were removed from the tea estate to promote adherence. There were no differences in loss to follow-up between groups: 108 and 104 women completed the study in the IS and DFS group, respectively. Adherence to the intervention was high and similar between treatment groups ${ }^{(24)}$.

\section{Follow-up procedures}

Participants were given deworming medication (albendazole, $200 \mathrm{mg}$ ) one month before the baseline (enrolment) blood draw and after five months of follow-up (midpoint). Venous blood samples were collected at baseline and endline (after ten months of follow-up). Single casual urine samples were collected at baseline and endline to assess iodine excretion. Height $(\mathrm{cm})$ and weight $(\mathrm{kg})$ were measured by trained anthropometrists at baseline and endline. BMI was calculated as weight $(\mathrm{kg}) /$ height $^{2}\left(\mathrm{~m}^{2}\right)$. Participant age, ethnicity and socio-economic indicators were assessed via questionnaires, as detailed in Haas et al. ${ }^{(24)}$.

\section{Laboratory analyses}

Venous blood samples were analysed for $\mathrm{Hb}$, serum ferritin (sFt) and soluble transferrin receptor (TfR). Inflammation was assessed via measurement of C-reactive protein (CRP) and $\alpha_{1}$-acid glycoprotein (AGP). Hb was assessed with a Coulter Counter (Beckman). sFt and CRP were analysed by chemiluminescent immunoassay (Immulite 2000) and AGP by radial immunodiffusion (Kent Laboratories). ELISA was used to assess TfR (BioVendor, Asheville, NC, USA), and a subgroup of blood samples ( $n 35)$ were run in duplicate with an ELISA kit from Ramco Laboratories (Stafford, TX, USA) to calculate Ramco-adjusted TfR values by linear regression ${ }^{(24)}$. The resulting prediction equation was: $\operatorname{TfR}_{\text {Ramco }}=1.821 \times \mathrm{TfR}_{\text {BioVendor }}^{0.739}$. Total body Fe (BI) was estimated with Cook's equation ${ }^{(31)}$, which required Ramco-adjusted TfR values, as: $\mathrm{BI}=-\left[\log \left(\mathrm{TfR}_{\text {Ramco }} / \mathrm{sFt}\right)-2 \cdot 8229\right] / 0 \cdot 1207$. Serum folate, vitamin $\mathrm{B}_{12}$ and urinary iodine were also measured at baseline and endline with the Immulite 2000. The $\mathrm{Hb}, \mathrm{sFt}$, CRP and iodine tests were completed at the Clinical Research Services of Super Religare Laboratory, Kolkata branch, India. Analyses of TfR, AGP, folate and vitamin $\mathrm{B}_{12}$ were performed at the Molecular Diagnostics Laboratory in Lucknow, India.

\section{Statistical analyses}

Data processing and statistical analyses were performed using the statistical software package SAS version 9.4. Where applicable, non-parametric analyses were used for non-normally distributed measures. sFt and BI were examined both without adjustment and with Thurnham's correction factor for inflammation ${ }^{(32)}$. Values for $\mathrm{sFt}$, and 
thus for BI, were corrected only if a participant had CRP $>3.0 \mathrm{mg} / \mathrm{l}, \mathrm{AGP}>1.0 \mathrm{~g} / \mathrm{l}$, or both. The Bonferroni method $^{(33)}$ was used to correct for multiple comparisons when necessary.

The resolution of deficiency is often used as a metric in clinical settings to determine the efficacy of nutrition interventions. While this is a useful method, it may not account for false negatives; that is, individuals who were severely deficient or who had low but technically sufficient status before the intervention and who nevertheless demonstrate large increases in status at endline. To address this, we used three different assessments of response: absolute change, relative change and resolution of deficiency. The first assessment utilized an epidemiological approach, which examined the absolute change in Fe biomarkers. For this assessment, multivariate linear regression models were developed to identify predictors of change in $\mathrm{Hb}, \mathrm{sFt}$ and $\mathrm{BI}$ across the intervention, which replicates the results of Haas et al. ${ }^{(24)}$. We chose these indicators to assess multiple components of Fe status: Hb for anaemia, sFt for Fe stores, and $\mathrm{BI}$ for a composite estimate of $\mathrm{Fe}$ in both tissues and stores. A negative BI value indicates Fe deficiency ${ }^{(31)}$. The second assessment, used in public health evaluations, measured response to the intervention as a relative change in Fe biomarkers ${ }^{(34)}$. Responders were defined as those whose sFt, BI or $\mathrm{Hb}$ increased more than $1 \mathrm{sD}$ above the mean change for the control group. We selected this cut-off for response because it is outside the known day-to-day biomarker variation ${ }^{(35)}$ and also captures sample-specific response. Finally, we studied the resolution of deficiency. Resolvers were defined as women who had Fe deficiency (defined as $\mathrm{sFt}<12.0 \mu \mathrm{g} / \mathrm{l}$ ), low $\mathrm{BI}(\mathrm{BI}<0.0 \mathrm{mg} / \mathrm{kg})$ or anaemia at baseline and were $\mathrm{Fe}$ replete at endline. These are standard cut-off values for deficiency $^{(36)}$. We also examined a less stringent definition of Fe depletion $(\mathrm{sFt}<15 \cdot 0 \mu \mathrm{g} / \mathrm{l})^{(36,37)}$. Non-resolvers were deficient at baseline and remained deficient at endline. For both the relative change and deficiency resolution methods, predictors of response to the intervention were identified using Hodges-Lehmann-Sen estimations ${ }^{(38)}, \chi^{2}$ tests and binomial regression models (to estimate relative risk).

The following variables were considered as covariates as well as potential predictors of benefit: age, measures of baseline Fe status ( $\mathrm{Hb}$, anaemia $(\mathrm{Hb}<120 \mathrm{~g} / \mathrm{l}$; yes or no) and TfR) and anthropometry (weight, height and $\mathrm{BMI}$ ). Baseline serum folate and vitamin $\mathrm{B}_{12}$ were evaluated because deficiencies in these nutrients can result in anaemia ${ }^{(39)}$. Women were considered deficient in folate or vitamin $\mathrm{B}_{12}$ with folate $<5 \mathrm{ng} / \mathrm{ml}$ or vitamin $\mathrm{B}_{12}<200 \mathrm{pg} / \mathrm{ml}^{(39)}$. Baseline urinary iodine was included because all of the intervention salt was iodized. Ethnicity (Adivasi or Nepali) was included as a random effect.

As the study was not designed to identify predictors of Fe deficiency or low BI resolution, a less stringent requirement of significance $(P<0 \cdot 1)$ was used for initial univariate regression analyses and interaction terms in multivariate analyses. Significant variables from the univariate models were retained in the multivariate binomial regression models to predict resolution of Fe deficiency and low $\mathrm{BI}$ if the $P$ value was $<0.05$ or $<0.1$ for interactions. All tests were two-tailed.

\section{Results}

The baseline characteristics were the same in the present sub-sample as in Haas et al. ${ }^{(24)}$ and did not differ between treatment groups (see online supplementary material, Supplemental Table S1). We first examine those who benefited from the intervention using the three methods of assessing response described above and then identify baseline characteristics that predict potential to benefit from the DFS intervention.

\section{Absolute change in biomarkers across the intervention}

We included change in sFt, $\mathrm{BI}$ and $\mathrm{Hb}$ as continuous dependent variables in multivariate linear regression models (Table 1). Both baseline $\log (\mathrm{sFt})$ and treatment group predicted change in $\log (\mathrm{sFt})(P<0.001)$. The interaction term did not reach statistical significance (Table 1). Although lower baseline $\log (\mathrm{sFt})$ concentrations resulted in greater change in $\log (\mathrm{sFt})$, the effect was more pronounced in the DFS $v$. IS group (Fig. 1). Women who received DFS had greater increases in $\mathrm{BI}$ relative to those who received IS and baseline BI was negatively associated with change in BI $(P<0.001)$ when the interaction between baseline BI and treatment group was not included in the model (data not shown). The interaction between baseline BI and treatment group was significant $(P=0.08$; Table 1$)$. Ethnicity and baseline $\mathrm{Hb}$ predicted the change in $\mathrm{Hb}$, but treatment group did not (Table 1). The interaction between ethnicity and treatment did not predict change in $\mathrm{sFt}, \mathrm{BI}$ or $\mathrm{Hb}$ (data not shown).

Figure 1 shows that the effect of treatment on the change in both $\log (\mathrm{sFt})$ and BI was statistically significant only among women in the lowest quartile of sFt and the lowest half of the BI distribution at baseline, respectively. Change in $\mathrm{Hb}$ did not vary by treatment group at any level of baseline $\mathrm{Hb}$ and therefore was not included in later regression analyses.

\section{Relative change in biomarkers across the intervention}

We next evaluated responders as those whose $\mathrm{sFt}$ or BI increased more than $1 \mathrm{SD}$ above the mean change for the control group: $>0.31 \mu \mathrm{g} / \mathrm{l}$ change in $\log (\mathrm{sFt})$ and $>2.76 \mathrm{mg} / \mathrm{kg}$ change in BI, respectively. Treatment with DFS $(P<0.01)$ and baseline $s F t<12.0 \mu \mathrm{g} / 1 \quad(P<0.001)$, $\mathrm{BI}<0.0 \mathrm{mg} / \mathrm{kg}(P<0.001)$ and TfR $>8.6 \mathrm{mg} / \mathrm{l}(P<0.001)$ 
Predicting benefit from an iron intervention

Table 1 Multivariate baseline predictors of changes in serum ferritin, body iron and $\mathrm{Hb}$ in response to an intervention of double-fortified salt in female Indian tea pluckers

\begin{tabular}{|c|c|c|c|c|c|c|}
\hline \multirow[b]{2}{*}{ Independent variable } & \multicolumn{2}{|c|}{$\begin{array}{l}\text { Change in log(sFt) } \\
(\log (\mu \mathrm{g} / \mathrm{l}) ; n 212)\end{array}$} & \multicolumn{2}{|c|}{$\begin{array}{l}\text { Change in BI } \\
(\mathrm{mg} / \mathrm{kg} ; n 211)\end{array}$} & \multicolumn{2}{|c|}{$\begin{array}{c}\text { Change in } \mathrm{Hb} \\
(\mathrm{g} / \mathrm{l} ; n 212)\end{array}$} \\
\hline & Estimate & SE & Estimate & SE & Estimate & SE \\
\hline Intercept & $0.66^{\star \star \star}$ & 0.05 & $3 \cdot 85^{\star \star \star}$ & 0.43 & $5 \cdot 05^{\star \star \star}$ & 0.77 \\
\hline Baseline $\log (s F t)(\log (\mu g / l))$ & $-0.32^{\star \star *}$ & 0.03 & - & - & - & - \\
\hline Baseline BI (mg/kg) & - & - & $-0.47^{\star \star *}$ & 0.05 & - & - \\
\hline Baseline $\mathrm{Hb}(\mathrm{g} / \mathrm{l})$ & - & - & - & - & $-0.04^{\star \star *}$ & 0.01 \\
\hline Treatment (DFS) $\ddagger$ & $0.13^{\star \star \star}$ & 0.03 & $1.95^{\star \star \star}$ & 0.32 & 0.90 & 1.06 \\
\hline Ethnicity (Adivasi) $\ddagger$ & - & - & - & - & $-0.51^{\star \star \star}$ & 0.12 \\
\hline Baseline $\log (\mathrm{sFt}) \times$ Treatment $(\log (\mu \mathrm{g} / \mathrm{l})) \ddagger$ & $0 \cdot 10$ & 0.07 & - & - & - & - \\
\hline Baseline $\mathrm{BI} \times$ Treatment $(\mathrm{mg} / \mathrm{kg}) \ddagger$ & - & - & $-0.11 \dagger$ & 0.06 & - & - \\
\hline Baseline $\mathrm{Hb} \times$ Treatment $(\mathrm{g} / \mathrm{l}) \ddagger$ & - & - & - & - & 0.006 & 0.009 \\
\hline
\end{tabular}

$\mathrm{sFt}$, serum ferritin; $\mathrm{BI}$, estimated total body Fe; DFS, double-fortified salt.

$\dagger P<0.1 ;{ }^{*} P<0.05 ;{ }^{* \star *} P<0.001$.

fReference values for independent variables: treatment, iodized salt; ethnicity, Nepali.

(a)

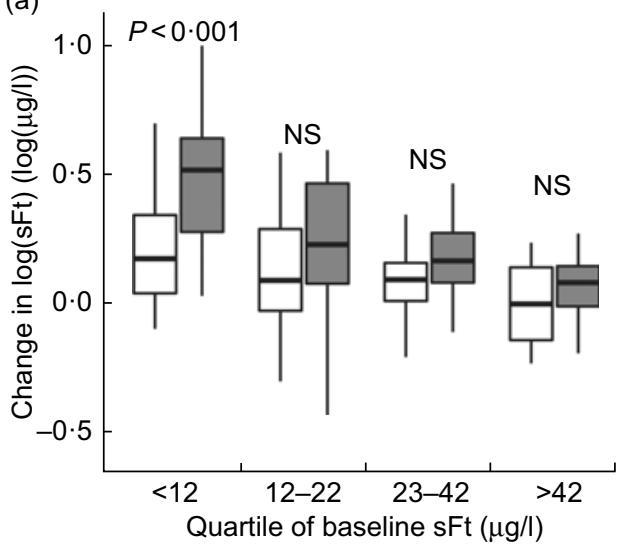

(c)

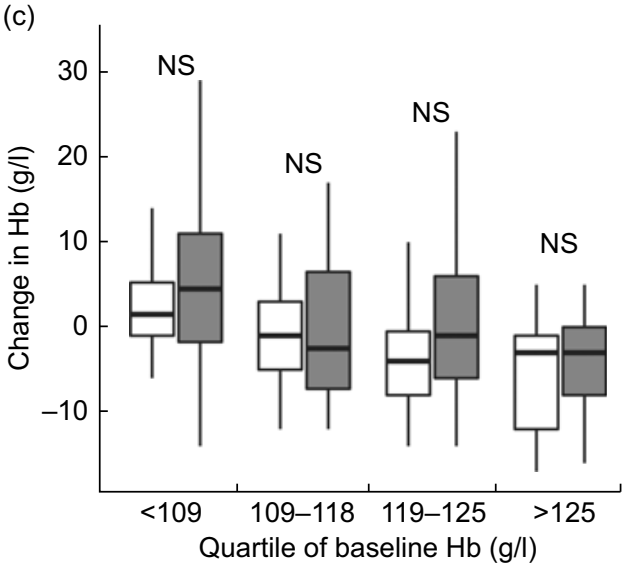

(b)

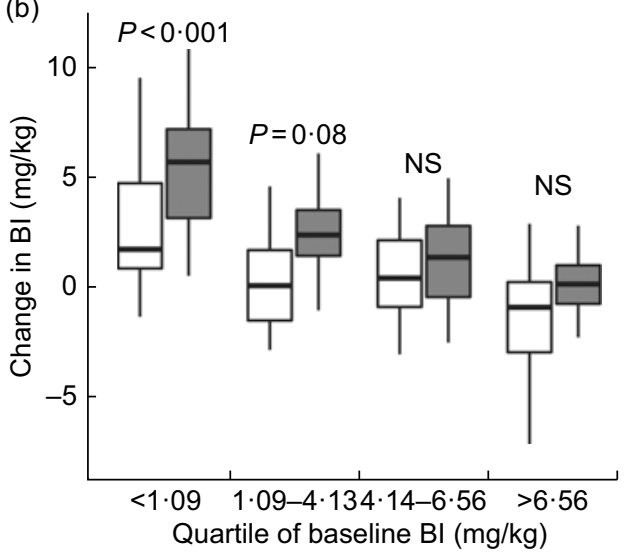


Table 2 Baseline predictors of relative response $\ddagger$ in iron status to an intervention of double-fortified salt in female Indian tea pluckers: univariate analysis

\begin{tabular}{|c|c|c|c|c|}
\hline \multirow[b]{2}{*}{ Independent variable } & \multicolumn{2}{|c|}{$\begin{array}{c}\mathrm{sFt} \\
(n 212)\end{array}$} & \multicolumn{2}{|c|}{$\begin{array}{c}\mathrm{BI} \\
(n 211)\end{array}$} \\
\hline & $\mathrm{RR} \ddagger$ & $95 \% \mathrm{Cl}$ & $\mathrm{RR} \ddagger$ & $95 \% \mathrm{Cl}$ \\
\hline Age (years) & 0.98 & 0.95 & $0.97 \dagger$ & 0.95 \\
\hline & 93 & 0.56 & .10 & $0.64,1.60$ \\
\hline$\therefore$ & .98 & $0.94,1.03$ & 0.99 & $0.95,1.04$ \\
\hline$+(1)$ & .00 & $97,1.03$ & 0.99 & $.96,1.02$ \\
\hline BMI ( & 1.01 & $0.93,1.09$ & 0.97 & $0.89,1.05$ \\
\hline Treatment§ & $2 \cdot 28^{\star *}$ & $1.32,3.95$ & $2 \cdot 32^{\star *}$ & $1.40,3.84$ \\
\hline $\mathrm{Hb}(\mathrm{g} / \mathrm{l})$ & $0.67^{\star \star}$ & $0.53,0.85$ & $0.76^{*}$ & $0.62,0.94$ \\
\hline & $0.94^{\star \star \star}$ & $0.91,0.96$ & $0.96^{\star \star *}$ & $0.94,0.98$ \\
\hline $\operatorname{TfR}(\mathrm{r}$ & $1.02^{*}$ & $1.00,1.05$ & $\mathrm{NC}$ & $\mathrm{NC}$ \\
\hline $\mathrm{BI}(\mathrm{m}$ & NC & $\mathrm{NC}$ & $\mathrm{NC}$ & NC \\
\hline$(\mathrm{ng} / \mathrm{ml})$ & 0.97 & $0.84,1.13$ & 0.90 & $0.77,1.05$ \\
\hline Vitamin $\mathrm{B}_{12}(\mathrm{pg} / \mathrm{ml})$ & 1.00 & $1.00,1.00$ & 1.00 & $1.00,1.00$ \\
\hline & 1.00 & $1.00,1.00$ & 1.00 & $1.00,1.00$ \\
\hline $\mathrm{H}$ & 1.29 & 0.7 & 1.32 & $0.84,2.08$ \\
\hline BMI & 1.11 & $0.68,1.83$ & 1.34 & $0.86,2.12$ \\
\hline $\mathrm{sFt}<12.0 \mu \mathrm{g} / \mathrm{l}$ & $3 \cdot 64^{\star \star *}$ & $2 \cdot 26,5 \cdot 84$ & $2 \cdot 75^{\star \star \star}$ & $1 \cdot 79,4 \cdot 23$ \\
\hline $\mathrm{TfR}>8.6 \mathrm{mg} / \mathrm{l}$ & $3.05^{\star \star \star}$ & $1.92,4.86$ & $3 \cdot 01^{\star \star \star}$ & $1.98,4.57$ \\
\hline $\mathrm{BI}<0 \mathrm{mg} / \mathrm{kg}$ & $4.03^{\star \star \star}$ & $2 \cdot 54,6 \cdot 39$ & $3.58^{\star \star \star}$ & $2.37,5.41$ \\
\hline$(\mathrm{Hb}<120 \mathrm{~g} / \mathrm{l})$ & 1.46 & $0.87,2.45$ & $1 \cdot 13$ & $0.71,1.79$ \\
\hline Folat & 1.84 & $0.71,4 \cdot 76$ & $2 \cdot 14$ & $0.83,5.48$ \\
\hline $3 \mathrm{pg} / \mathrm{ml}$ & 1.38 & $0.84,2 \cdot 26$ & 1.08 & $0.68,1.72$ \\
\hline lodine $<100 \mu \mathrm{g} / \mathrm{l}$ & 0.77 & $0.46,1.29$ & 0.92 & $0.58,1.46$ \\
\hline
\end{tabular}

$\mathrm{sFt}$, serum ferritin; $\mathrm{BI}$, estimated total body Fe; RR, relative risk; TfR, soluble transferrin receptor; NC, model did not converge.

$\dagger P<0.1 ;{ }^{*} P<0.05 ;{ }^{* \star} P<0.01 ;{ }^{* \star *} P<0.001$.

†Relative response defined as increase in Fe biomarkers more than $1 \mathrm{sD}$ above the mean of the change in the control group; change in $\log (\mathrm{sFt})>0.31 \mu \mathrm{g} /$; change in $\mathrm{BI}>2.76 \mathrm{mg} / \mathrm{kg}$.

$\S$ Reference values for independent variables: ethnicity, Adivasi; treatment, iodized salt.

$\|$ Corrected by Ramco assay.

predicted response both in sFt and BI (Table 2). Every $1.0 \mathrm{~g} / \mathrm{l}$ decrease in baseline $\mathrm{Hb}(P<0.01)$ and $1.0 \mu \mathrm{g} / \mathrm{l}$ decrease in baseline $s \mathrm{Ft}(P<0.001)$ predicted response for both sFt and BI. Each $1.0 \mathrm{mg} / \mathrm{l}$ increase in baseline TfR (relative risk $(\mathrm{RR})=1.02, P<0.05)$ predicted response in sFt. Models for baseline BI did not converge.

\section{Resolution of deficiency}

Resolution of deficiency is commonly used to evaluate the success of nutrition interventions, e.g. ${ }^{(40,41)}$. We examined several definitions of the resolution of Fe deficiency, low BI and anaemia by treatment group with univariate binomial regression models (Table 3$)$. Only the RR for resolution of baseline $\mathrm{sFt}<12.0 \mu \mathrm{g} / \mathrm{l}(\mathrm{RR}=2.31$ in DFS $v$. IS, $P=0.01)$ and $\mathrm{BI}<0.0 \mathrm{mg} / \mathrm{kg}(\mathrm{RR}=2.78$ in DFS, $P=0.01)$ differed significantly by treatment group, although RR for resolution of baseline anaemia approached significance $(P=0.07)$. Some studies use a less stringent definition of Fe deficiency; thus, we also examined the resolution of $\mathrm{sFt}<15 \mu \mathrm{g} / \mathrm{l}^{(37)}$. This cut-off had some discriminatory value; the RR for resolution approached statistical significance in this sample $(P=0.06)$.

\section{Baseline characteristics of resolution}

Results were similar for sFt and BI, and thus only BI results are presented here. Baseline characteristics of participants are shown in Tables 4 and 5 by resolution group: nondeficient women with baseline $\mathrm{BI} \geq 0.0 \mathrm{mg} / \mathrm{kg}$ and deficient women with baseline $\mathrm{BI}<0.0 \mathrm{mg} / \mathrm{kg}$. Women with low baseline BI were further divided into resolvers (BI $>0.0 \mathrm{mg} / \mathrm{kg}$ at endline) or non-resolvers. All baseline Fe biomarkers were lower in those with baseline low BI compared with those with normal baseline BI status, but only sFt and BI differed between resolvers and non-resolvers: $7.0 \mu \mathrm{g} / 1 v .4 .0 \mu \mathrm{g} / \mathrm{l}$ for $\mathrm{sFt}$ and $-1.6 \mathrm{mg} / \mathrm{kg}$ v. $-4.8 \mathrm{mg} / \mathrm{kg}$ for $\mathrm{BI}$, respectively $(P<0.05)$. CRP was elevated in those with normal baseline Fe status compared with resolvers $(P<0.05)$. Resolvers were shorter than women with normal baseline Fe status $(P<0.05$; Table 4$)$.

Table 5 shows that a greater proportion of resolvers were in the DFS group compared with the non-resolvers and those with normal baseline BI status. Prevalence of anaemia was also greater in the resolvers and non-resolvers compared with those with normal baseline $\mathrm{Fe}$ status $(P<0.05)$. Baseline folate, vitamin $\mathrm{B}_{12}$ and iodine did not differ between groups, and there was a high prevalence of folate $(>85 \%)$ and vitamin $\mathrm{B}_{12}(>34 \%)$ deficiencies in this sample. Participants with normal baseline Fe values were somewhat more likely to have baseline AGP $>1.0 \mathrm{~g} / 1$ compared with non-resolvers $(P<0.09)$ after accounting for multiple comparisons.

Change in Fe biomarkers from baseline to endline differed between resolvers and non-resolvers (Table 6). Change in sFt, TfR and BI was significantly different between $\mathrm{BI}$ resolution groups $(P<0 \cdot 01)$. Change in $\mathrm{Hb}$ did not differ between BI resolvers and non-resolvers $(P=0 \cdot 1)$. Urinary iodine changed similarly between resolution groups, and folate and vitamin $\mathrm{B}_{12}$ concentrations did not change from baseline to endline in either resolution group.

Univariate binomial regression models revealed DFS treatment and baseline BI predicted resolution of $\mathrm{BI}<0.0 \mathrm{mg} / \mathrm{kg}(P=0.01$, Table 7$)$. No multivariate models significantly predicted resolution of $\mathrm{sFt}<12.0 \mu \mathrm{g} / \mathrm{l}$ or $\mathrm{BI}<0.0 \mathrm{mg} / \mathrm{kg}$ (data not shown).

\section{Discussion}

In order to respond to DFS, one must have a potential to benefit from the intervention. Fe status is controlled by absorption rather than excretion mechanisms. Thus, women with low Fe status at baseline are expected to absorb more Fe, resulting in a greater increase in Fe concentration than in women with higher baseline Fe status ${ }^{(42)}$.

Using as a foundation the biological plausibility analyses presented in Haas et al. ${ }^{(24)}$, which reported greater increases in the change in BI with lower baseline Fe status, we aimed to identify distinguishing characteristics of 
Table 3 Resolution of deficiency by various measures of iron status and anaemia in female Indian tea pluckers by treatment group

\begin{tabular}{|c|c|c|c|c|c|c|c|}
\hline \multirow[b]{2}{*}{ Baseline marker of deficiency } & \multirow[b]{2}{*}{$N$} & \multicolumn{2}{|c|}{$\begin{array}{l}\text { Resolution in IS } \\
\text { group }\end{array}$} & \multicolumn{2}{|c|}{$\begin{array}{l}\text { Resolution in DFS } \\
\text { group }\end{array}$} & \multirow[b]{2}{*}{ RR $\ddagger$} & \multirow[b]{2}{*}{$95 \% \mathrm{Cl}$} \\
\hline & & $n$ & $\%$ of IS & $n$ & $\%$ of DFS & & \\
\hline $\mathrm{sFt}<12.0 \mu \mathrm{g} / \mathrm{l}$ & 52 & 8 & $32 \cdot 0$ & 20 & $74 \cdot 1$ & $2 \cdot 31^{*}$ & $1.25,4.27$ \\
\hline $\mathrm{sFt}<15.0 \mu \mathrm{g} / \mathrm{l}$ & 65 & 12 & $36 \cdot 4$ & 19 & $59 \cdot 4$ & $1.63 \dagger$ & $0.96,2.79$ \\
\hline $\mathrm{Hb}<120 \mathrm{~g} / \mathrm{l}$ & 113 & 5 & 8.6 & 12 & 21.8 & $2.53 \dagger$ & $0.95,6.72$ \\
\hline $\mathrm{BI}<0.0 \mathrm{mg} / \mathrm{kg}$ & 45 & 5 & $26 \cdot 3$ & 19 & $73 \cdot 1$ & $2 \cdot 78^{*}$ & $1 \cdot 26,6 \cdot 10$ \\
\hline
\end{tabular}

IS, iodized salt; DFS, double-fortified salt; RR, relative risk; sFt, serum ferritin; BI, estimated total body Fe.

$\dagger P<0.1 ;{ }^{*} P<0.05$.

$\ddagger$ Risk of resolution, reference group: IS.

Table 4 Baseline median haematological characteristics of Indian female tea pluckers grouped according to resolution of low body iron after a double-fortified salt intervention

\begin{tabular}{|c|c|c|c|c|c|c|}
\hline \multirow[b]{3}{*}{ Baseline variable } & \multirow{2}{*}{\multicolumn{2}{|c|}{$\begin{array}{c}\text { Baseline } \mathrm{BI} \geq 0 \mathrm{mg} / \mathrm{kg} \\
(n 167)\end{array}$}} & \multicolumn{4}{|c|}{ Baseline $\mathrm{BI}<0 \mathrm{mg} / \mathrm{kg}$} \\
\hline & & & \multicolumn{2}{|c|}{$\begin{array}{l}\text { Non-resolvers } \ddagger \\
\quad(n 21)\end{array}$} & \multicolumn{2}{|c|}{$\begin{array}{l}\text { Resolvers } \ddagger \\
\quad(n 24)\end{array}$} \\
\hline & Median & IQR & Median & IQR & Median & IQR \\
\hline Age (years) & 40 & 35,45 & 40 & 34,45 & 40 & 30,45 \\
\hline Weight (kg) & 43.8 & $38 \cdot 9,49 \cdot 1$ & $40 \cdot 2$ & $37 \cdot 6,46 \cdot 7$ & $40 \cdot 4$ & $37 \cdot 7,48 \cdot 75$ \\
\hline Height $(\mathrm{cm})$ & $150 \cdot 8$ & $147 \cdot 1,154 \cdot 2$ & $148 \cdot 0$ & $146 \cdot 2,152 \cdot 3$ & $148 \cdot 3$ & $146 \cdot 1,150 \cdot 8$ \\
\hline $\operatorname{BMI}\left(\mathrm{kg} / \mathrm{m}^{2}\right)$ & $19 \cdot 4$ & $17 \cdot 4,21 \cdot 2$ & $17 \cdot 9$ & $17 \cdot 3,20 \cdot 6$ & $19 \cdot 0$ & $17 \cdot 1,21 \cdot 3$ \\
\hline $\mathrm{Hb}(\mathrm{g} / \mathrm{l})$ & $120^{\mathrm{a}}$ & 111,126 & $107^{b}$ & 102,112 & $109^{b}$ & 102,122 \\
\hline $\mathrm{sFt}(\mu \mathrm{g} / \mathrm{l})$ & $30 \cdot 0^{\mathrm{a}}$ & 18,51 & $4 \cdot 0^{\mathrm{b}}$ & $4 \cdot 0,5 \cdot 0$ & $7 \cdot 0^{\mathrm{c}}$ & 6,10 \\
\hline $\operatorname{TfR}(\mathrm{mg} / \mathrm{l}) \S$ & $4 \cdot 65^{a}$ & $2.95,6.40$ & $10 \cdot 9^{b}$ & $8.4,12 \cdot 4$ & $10 \cdot 6^{\mathrm{b}}$ & $7 \cdot 1,13 \cdot 9$ \\
\hline $\mathrm{BI}(\mathrm{mg} / \mathrm{kg})$ & $5 \cdot 2^{\mathrm{a}}$ & $3.43,7.70$ & $-4 \cdot 8^{b}$ & $-6 \cdot 6,-2 \cdot 9$ & $-1.6^{\mathrm{d}}$ & $-4 \cdot 8,-1 \cdot 1$ \\
\hline Folate (ng/ml) & 3.41 & $2 \cdot 46,4.22$ & $4 \cdot 10$ & $2.58,4.78$ & 3.44 & $2.07,4.52$ \\
\hline Vitamin $\mathrm{B}_{12}(\mathrm{pg} / \mathrm{ml})$ & 223 & 185,311 & 237 & 197,316 & 225 & 164,294 \\
\hline lodine $(\mu \mathrm{g} / \mathrm{l})$ & 115 & 66,225 & 165 & 72,234 & 127 & 81,186 \\
\hline CRP (mg/l) & $0.8^{\mathrm{b}}$ & $0.5,1.3$ & $0.7^{b, c}$ & $0.5,1.2$ & $0.5^{\mathrm{c}}$ & $0.5,0.7$ \\
\hline AGP $(g / l)$ & 0.67 & $0.55,1.02$ & 0.70 & $0.53,0.88$ & 0.70 & $0.52,1.00$ \\
\hline
\end{tabular}

$\mathrm{BI}$, estimated total body Fe; IQR, interquartile range; sFt, serum ferritin; TfR, transferrin receptor; CRP, C-reactive protein; AGP, $\alpha_{1}$-acid glycoprotein.

$\mathrm{a}, \mathrm{b}, \mathrm{c}, \mathrm{d}$ Median values within a row with unlike superscript letters were significantly different by the Hodges-Lehman-Sen test; $P$ values for differences are $<0.01$ unless marked as b v. c $(P<0.05)$.

¥Non-resolvers, $\mathrm{BI}<0.0 \mathrm{mg} / \mathrm{kg}$ at endline; resolvers, $\mathrm{BI} \geq 0.0 \mathrm{mg} / \mathrm{kg}$ at endline.

$\S$ Corrected by Ramco assay.

individuals whose Fe status improved after the intervention $v$. individuals with no change - either absolute or relative in Fe status. We replicated the findings of Haas et al. that consuming DFS predicted a greater increase in BI. We also observed a significant change in sFt in response to DFS consumption $^{(24)}$

Unexpectedly, we found only a marginal increase in $\mathrm{Hb}$ among women consuming DFS $v$. IS who were anaemic at baseline. Although anaemia is often used as an inexpensive measure of low Fe status ${ }^{(43,44)}$, Hb does not decrease to anaemic status until Fe stores are nearly completely depleted $^{(11)}$ and a recent meta-analysis found that, worldwide, less than $40 \%$ of anaemia in women of reproductive age is due to Fe deficiency ${ }^{(37)}$. Anaemia can also be caused by a variety of nutrient deficiencies, including folate and vitamin $\mathrm{B}_{12}{ }^{(39)}$, which were not affected by this Fe intervention. Consequently, $\mathrm{Hb}$ may not be an appropriate measure for predicting responsiveness to DFS in populations with a similarly high prevalence of folate and vitamin $\mathrm{B}_{12}$ deficiencies.
In addition to the analyses of continuous change, we studied predictors of relative change in Fe biomarkers. This technique identified similar predictors of response as in the absolute change analyses and may be useful for targeting interventions using baseline $\mathrm{Hb}$, as this was the only analysis in which baseline $\mathrm{Hb}$ predicted response in $\mathrm{sFt}$ or $\mathrm{BI}$ (see Table 2). As with any method that relies on a cut-off, this approach has the limitation of potentially misclassifying true responders as non-responders because women with marginally low to normal $\mathrm{Fe}$ status at baseline would be expected to have only small increases post-intervention.

To examine the greater public health and clinical implications of DFS, we also analysed predictors of resolution of Fe deficiency and low BI. By definition, baseline Fe biomarkers were higher in those with normal baseline Fe status. Thus, those individuals had less potential to benefit from the intervention $v$. those with low baseline Fe concentrations. We expected those with lower Fe status to have the greatest response to the intervention. However, women 
Table 5 Baseline prevalence of demographic and haematological status of Indian female tea pluckers grouped according to resolution of low body iron after a double-fortified salt intervention

\begin{tabular}{|c|c|c|c|c|c|c|}
\hline \multirow[b]{3}{*}{ Baseline variable } & \multirow{2}{*}{\multicolumn{2}{|c|}{$\begin{array}{l}\text { Baseline } \mathrm{BI} \geq 0 \mathrm{mg} / \mathrm{kg} \\
(n 167)\end{array}$}} & \multicolumn{4}{|c|}{ Baseline $\mathrm{Bl}<0 \mathrm{mg} / \mathrm{kg}$} \\
\hline & & & \multicolumn{2}{|c|}{$\begin{array}{l}\text { Non-resolvers } \ddagger \\
(n 21)\end{array}$} & \multicolumn{2}{|c|}{$\begin{array}{l}\text { Resolvers } \ddagger \\
\quad(n 24)\end{array}$} \\
\hline & $n$ & $\%$ & $n$ & $\%$ & $n$ & $\%$ \\
\hline Treatment: DFS & 78 & $46 \cdot 7^{a}$ & 7 & $33.3^{a}$ & 19 & $79 \cdot 2^{b}$ \\
\hline Ethnicity: Adivasi & 91 & 54.5 & 15 & 71.4 & 14 & $58 \cdot 3$ \\
\hline Ethnicity: Nepali & 76 & 45.5 & 6 & $28 \cdot 6$ & 10 & 41.7 \\
\hline Height $<150 \mathrm{~cm}$ & 68 & $40 \cdot 7^{a}$ & 12 & $57 \cdot 1^{a, b}$ & 17 & $70 \cdot 8^{\mathrm{b}}$ \\
\hline $\mathrm{BMI}<19.0 \mathrm{~kg} / \mathrm{m}^{2}$ & 72 & $43 \cdot 1$ & 13 & $61 \cdot 0$ & 11 & $45 \cdot 8$ \\
\hline $\mathrm{Hb}<120 \mathrm{~g} / \mathrm{l}$ & 79 & $47 \cdot 3^{a}$ & 18 & $85 \cdot 7^{\mathrm{b}, \mathrm{c}}$ & 16 & $66 \cdot 7^{b}$ \\
\hline Folate $<5.0 \mathrm{ng} / \mathrm{ml}$ & 142 & $86 \cdot 1$ & 17 & $85 \cdot 0$ & 20 & 83.3 \\
\hline Vitamin $\mathrm{B}_{12}<203 \mathrm{pg} / \mathrm{ml}$ & 61 & $36 \cdot 8$ & 8 & $40 \cdot 0$ & 11 & $45 \cdot 8$ \\
\hline lodine $<100 \mu \mathrm{g} / \mathrm{l}$ & 74 & $44 \cdot 3$ & 9 & 42.9 & 10 & 41.7 \\
\hline $\mathrm{CRP}>5.0 \mathrm{mg} / \mathrm{l}$ & 9 & 5.4 & 1 & 4.8 & 0 & 0.0 \\
\hline$A G P>1.0 \mathrm{~g} / \mathrm{l}$ & 42 & 25.5 & 1 & $5 \cdot 0$ & 5 & $20 \cdot 8$ \\
\hline
\end{tabular}

$\mathrm{BI}$, estimated total body Fe; DFS, double-fortified salt; CRP, C-reactive protein; AGP, $\alpha_{1}$-acid glycoprotein.

a,b,c Percentage values within a row with unlike superscript letters were significantly different by the $\chi^{2}$ test; a $v$. b, $P<0.05$; a $v$. c, $P<0.01$. $\ddagger$ Non-resolvers, $\mathrm{BI}<0 \mathrm{mg} / \mathrm{kg}$ at endline; resolvers, $\mathrm{BI} \geq 0 \mathrm{mg} / \mathrm{kg}$ at endline.

Table 6 Changes in $\mathrm{Hb}$ and multiple micronutrient status indicators in the resolvers and non-resolvers of low body iron over the 10-month intervention of double-fortified salt among Indian female tea pluckers

\begin{tabular}{|c|c|c|c|c|}
\hline & \multicolumn{4}{|c|}{ Baseline $\mathrm{BI}<0 \mathrm{mg} / \mathrm{kg}$} \\
\hline & \multicolumn{2}{|c|}{$\begin{array}{l}\text { Non-resolvers } \ddagger \\
(n 21)\end{array}$} & \multicolumn{2}{|c|}{$\begin{array}{l}\text { Resolvers } \\
(n 24)\end{array}$} \\
\hline & Median & IQR & Median & IQR \\
\hline $\mathrm{Hb}(\mathrm{g} / \mathrm{l})$ & $-0 \cdot 1$ & $-0.3,0.4$ & 0.7 & $-0 \cdot 1,1 \cdot 2$ \\
\hline $\mathrm{sFt}(\mu \mathrm{g} / \mathrm{l})$ & $2 \cdot 0^{\mathrm{a}}$ & $1 \cdot 0,4 \cdot 0$ & $15 \cdot 5^{\mathrm{c}}$ & $10 \cdot 5,23.0$ \\
\hline $\operatorname{TfR}(\mathrm{mg} / \mathrm{l}) \S$ & $-1 \cdot 3^{a}$ & $-2.9,-0.6$ & $-4 \cdot 1^{b}$ & $-6 \cdot 6,-2 \cdot 2$ \\
\hline $\mathrm{BI}(\mathrm{mg} / \mathrm{kg})$ & $1.7^{a}$ & $1 \cdot 0,3 \cdot 3$ & $6 \cdot 3^{b}$ & $4.8,7 \cdot 6$ \\
\hline Folate $(\mathrm{ng} / \mathrm{ml})$ & 0 & 0,0 & 0 & 0,0 \\
\hline Vitamin $B_{12}(p g / m l)$ & 0 & 0,0 & 0 & 0,0 \\
\hline lodine $(\mu \mathrm{g} / \mathrm{l})$ & 15 & $-39,119$ & 58 & 2,165 \\
\hline
\end{tabular}

$\mathrm{BI}$, estimated total body $\mathrm{Fe}$; IQR, interquartile range; sFt, serum ferritin; TfR transferrin receptor.

$\mathrm{a}, \mathrm{b}, \mathrm{c}$ Median values within a row with unlike superscript letters were significantly different by the Hodges-Lehman-Sen test: a $v$. b, $P<0.01$; a $v$. c, $P<0.001$. $\ddagger$ Non-resolvers, $\mathrm{BI}<0 \mathrm{mg} / \mathrm{kg}$ at endline; resolvers, $\mathrm{BI} \geq 0 \mathrm{mg} / \mathrm{kg}$ at endline. $\S$ Corrected by Ramco assay.

with very low sFt and BI at baseline may not have been able to absorb sufficient Fe from DFS over ten months to resolve Fe deficiency, and thus the non-resolvers had lower baseline $\mathrm{sFt}$ than the resolvers in the univariate analyses (Table 4).

The body responds to inflammation by sequestering $\mathrm{Fe}$ in ferritin, resulting in elevated sFt concentrations that may mask Fe deficiency ${ }^{(32)}$ and affect prevalence estimation of deficiency $^{(45)}$. This phenomenon may explain why the group with normal sFt and BI at baseline had elevated baseline CRP values relative to those with Fe deficiency or low $\mathrm{BI}$ at baseline. If true, inflammation explains a similar relationship in $\mathrm{BI}$ resolution because the calculation of $\mathrm{BI}$ requires both $\mathrm{TfR}$ and $\mathrm{sFt} \mathrm{t}^{(31)}$.
There were no significant multivariate models of the resolution of Fe deficiency or low BI. However, the study was designed to identify a significant difference in the mean change in sFt concentrations between DFS and IS, and may not be sufficiently powered to detect differences in currently measured predictors of resolution. While resolution analyses are useful for identifying predictors of response and can be used to target future interventions in similar populations, they are limited because they do not account for the positive change in Fe biomarkers in those with an increased potential to benefit unless the change causes Fe concentration to cross a threshold marked by a given cut-off of deficiency. Further, such analyses do not account for increases in Fe status among women who had low but technically sufficient Fe status at baseline. Future interventions and programmes should consider the limitations of relying solely on resolution of deficiency as a benchmark for success and may benefit from using other or additional models of response, including the absolute and relative change models we present here.

Our goal was to understand the multiple underlying predictors of response to dietary Fe interventions. BI provides a composite measure of Fe status from severe deficiency to repletion, but is limited in some settings because it requires assessment of both sFt and TfR. Large public health interventions with limited resources and may require a smaller number of indicators. Although BI serves as a gold standard by permitting assessment across the range of resolution, our results show that measuring $\mathrm{sFt}$, perhaps in combination with $\mathrm{Hb}$, is a reasonable alternative to BI which will still adequately predict response to DFS interventions.

The present study was a randomized controlled trial, with successful randomization at baseline, appropriate sample size to test efficacy and reasonable compliance. The strong study design supports the robust secondary 
Table 7 Baseline univariate predictors of low body iron resolution to an intervention of double-fortified salt in female Indian tea pluckers

\begin{tabular}{|c|c|c|}
\hline \multirow[b]{2}{*}{ Independent variable } & \multicolumn{2}{|c|}{$\begin{array}{c}\mathrm{BI} \\
(n 45) \\
\end{array}$} \\
\hline & $\mathrm{RR} \ddagger$ & $95 \% \mathrm{Cl}$ \\
\hline Age (years) & 0.99 & $0.96,1.00$ \\
\hline Ethnicity§ & 1.29 & $0.76,2.21$ \\
\hline Height $(m) \|$ & 0.99 & $0.93,1.00$ \\
\hline Weight (kg) & 1.00 & $0.97,1.00$ \\
\hline $\operatorname{BMI}\left(\mathrm{kg} / \mathrm{m}^{2}\right) \|$ & 1.00 & $0.94,1 \cdot 10$ \\
\hline Treatment§ & $2 \cdot 78^{*}$ & $1 \cdot 26,6 \cdot 10$ \\
\hline $\mathrm{Hb}(\mathrm{g} / \mathrm{l})$ & 1.10 & $0.88,1.40$ \\
\hline $\mathrm{sFt}(\mu \mathrm{g} / \mathrm{l})$ & 1.00 & $0.98,1.10$ \\
\hline $\operatorname{TfR}(\mathrm{mg} / \mathrm{l})$ ๆ & 0.98 & $0.92,1.00$ \\
\hline $\mathrm{BI}(\mathrm{mg} / \mathrm{kg})$ & $1 \cdot 10^{\star}$ & $1.00,1.20$ \\
\hline Folate (ng/ml) & 0.92 & $0.77,1 \cdot 10$ \\
\hline Vitamin $\mathrm{B}_{12}(\mathrm{pg} / \mathrm{ml})$ & 1.00 & $1.00,1.00$ \\
\hline lodine $(\mu \mathrm{g} / \mathrm{l})$ & 1.00 & $1.00,1.00$ \\
\hline $\mathrm{sFt}<12.0 \mu \mathrm{g} / \mathrm{l}$ & NC & $\mathrm{NC}$ \\
\hline $\mathrm{TfR}>8.6 \mathrm{mg} / \mathrm{l}$ & 0.75 & $0.44,1.28$ \\
\hline Anaemia $(\mathrm{Hb}<120 \mathrm{~g} / \mathrm{l})$ & $0.65 \dagger$ & $0.39,1.08$ \\
\hline Folate $<5.0 \mathrm{ng} / \mathrm{ml}$ & 0.95 & $0.47,1.92$ \\
\hline Vitamin $B_{12}<203 \mathrm{pg} / \mathrm{ml}$ & 1.11 & $0.65,1.91$ \\
\hline lodine $<100 \mu \mathrm{g} / \mathrm{l}$ & 0.98 & $0.56,1.70$ \\
\hline
\end{tabular}

$\mathrm{BI}$, estimated total body $\mathrm{Fe}$; RR, relative risk; sFt, serum ferritin; TfR, transferrin receptor; $\mathrm{NC}$, model did not converge.

$+P<0.1 ;{ }^{*} P<0.05$.

$\neq \mathrm{BI}<0 \mathrm{mg} / \mathrm{kg}$ at baseline and $\mathrm{BI} \geq 0 \mathrm{mg} / \mathrm{kg}$ at endline.

$\S$ Reference values for independent variables: ethnicity, Adivasi; treatment, iodized salt.

$\|$ Height $<150 \mathrm{~cm}$ and $\mathrm{BMI}<19 \mathrm{~kg} / \mathrm{m}^{2}$ were also tested; results were not different from continuous variables.

ๆCorrected by Ramco assay.

analyses presented here. Although the randomized controlled trial design provides strong internal validity, the generalizability of the results is limited to other similar populations ${ }^{(25,27,29,42)}$. Thus, our findings can be applied to other populations of South Asian women of reproductive age, with high prevalence of Fe deficiency and of non-Fe deficiency anaemia, consuming DFS.

The results presented here are secondary analyses and cannot be interpreted with the same assumptions of causality as an intention-to-treat analysis. However, the results were confirmed with multiple types of analyses that defined response to the intervention by different criteria. The study may not have been adequately powered to identify all covariates which predict response to a DFS intervention. For example, although height at baseline differed slightly between the responders and those with no potential to benefit, height did not significantly predict response in the regression analyses.

\section{Conclusion}

DFS is increasing in popularity as a vehicle to resolve and prevent Fe deficiency, particularly among rural populations in low- and middle-income countries with limited access to dietary supplements or Fe-rich foods, and among populations with low adherence to dietary supplements ${ }^{(19,21-23,46)}$.
The present analyses demonstrate that salt double-fortified with microencapsulated ferrous fumarate and potassium iodate is a viable method for resolving Fe deficiency and low BI in this population. Importantly, we demonstrate that low concentrations of $\mathrm{BI}$ and $\mathrm{sFt}$ at baseline are the best predictors of response to a DFS intervention, regardless of whether individuals are clinically deficient at baseline. Further, measuring $\mathrm{Hb}$ alone may not be a sufficient marker of response, nor of potential to benefit from an intervention. Future studies evaluating DFS and programmes targeting similar interventions should: (i) replicate these findings in other populations; (ii) examine changes in sFt and $\mathrm{BI}$, in addition to $\mathrm{Hb}$, to better target $\mathrm{Fe}$ interventions, especially if there is a high prevalence of non-Fe deficiency anaemia in the population; and (iii) use these methods to evaluate the impact of DFS interventions on functional outcomes. Additionally, effectiveness studies are needed to test the ability of DFS to increase resolution of Fe deficiency in community settings $v$. an experimental field setting.

\section{Acknowledgements}

Acknowledgements: The authors thank Françoise Vermeylen for assistance in the early stages of data preparation and analysis, as well as Kim Harding from the Micronutrient Initiative (now Nutrition International) and Gregory Reinhart formerly from Mathile Institute for the Advancement of Human Nutrition for their helpful comments on the manuscript. Financial support: This study was supported by the Micronutrient Initiative (now Nutrition International), Ottawa, Canada; and the Mathile Institute for the Advancement of Human Nutrition, Dayton, OH, USA. Funders had no role in the design, analysis or writing of this article. Conflict of interest: J.D.H. was a paid consultant for and J.E.H.N. was supported by a stipend from the Micronutrient Initiative during this project. S.M. is an unpaid board member for a diagnostic start-up focused on measurement of nutritional biomarkers at the point of care utilizing the results from his research. Autborship: J.E.H.N. conducted the data analysis and contributed to writing the manuscript; S.V. supervised data collection and contributed to the data analysis and manuscript preparation; S.M. contributed to the data analysis and manuscript preparation; and J.D.H. developed the proposal, supervised data collection and analysis, contributed to writing the manuscript, and had primary responsibility for the final content. All authors read and approved the final manuscript. Ethics of human subject participation: This study was conducted according to the guidelines laid down in the Declaration of Helsinki and all procedures involving human subjects were approved by the institutional review boards at Cornell University, McGill University and the Child In Need Institute (Kolkata, India). Verbal informed consent was obtained from all subjects, and was witnessed 
and formally recorded. Clinical trial registry: This trial was registered at clinicaltrials.gov as NCT01032005.

\section{Supplementary material}

To view supplementary material for this article, please visit https://doi.org/10.1017/S1368980019001800

\section{References}

1. Stoltzfus RJ (2003) Iron deficiency: global prevalence and consequences. Food Nutr Bull 24, 4 Suppl., S99-S103.

2. Haas JD \& Brownlie T (2001) Iron deficiency and reduced work capacity: a critical review of the research to determine a causal relationship. J Nutr 131, 2S-2, 676S-690S.

3. Pasricha S-R, Low M, Thompson J et al. (2014) Iron supplementation benefits physical performance in women of reproductive age: a systematic review and meta-analysis. $J$ Nutr 144, 906-914.

4. Dao MC \& Meydani SN (2013) Iron biology, immunology, aging, and obesity: four fields connected by the small peptide hormone hepcidin. Adv Nutr 4, 602-617.

5. Beard JL \& Connor JR (2003) Iron status and neural functioning. Annu Rev Nutr 23, 41-58.

6. Murray-Kolb LE (2011) Iron status and neuropsychological consequences in women of reproductive age: what do we know and where are we headed? J Nutr 141, issue 4, 747S-755S.

7. Beard JL, Hendricks MK, Perez EM et al. (2005) Maternal iron deficiency anemia affects postpartum emotions and cognition. J Nutr 135, 267-272.

8. Lukowski AF, Koss M, Burden MJ et al. (2010) Iron deficiency in infancy and neurocognitive functioning at 19 years: evidence of long-term deficits in executive function and recognition memory. Nutr Neurosci 13, 54-70.

9. Black RE, Allen LH, Bhutta ZA et al. (2008) Maternal and child undernutrition: global and regional exposures and health consequences. Lancet 371, 1-17.

10. Yip R (2002) Prevention and control of iron deficiency: policy and strategy issues. J Nutr 132, 4 Suppl., 802S-805S.

11. World Health Organization (2001) Iron Deficiency Anaemia: Assessment, Prevention and Control. Geneva: WHO.

12. Lynch SR (2011) Why nutritional iron deficiency persists as a worldwide problem. J Nutr 141, issue 4, 763S-768S.

13. Beard JL (2001) Iron biology in immune function, muscle metabolism and neuronal functioning. $J$ Nutr 131, 2S-2, 568S-580S.

14. Holick MF (2007) Vitamin D deficiency. N Engl J Med 357 , 266-281.

15. Honein MA, Paulozzi LJ, Mathews TJ et al. (2001) Impact of folic acid fortification of the US food supply on the occurrence of neural tube defects. JAMA 285, 2981-2986.

16. Johnston RB (2008) Will increasing folic acid in fortified grain products further reduce neural tube defects without causing harm? Consideration of the evidence. Pediatr Res $\mathbf{6 3}, 2-8$.

17. Costello RB (2009) Vitamin D and health in the 21st century: federal initiatives to advance research. Am J Med Sci 338, 34-39.

18. Zimmermann MB (2009) Iodine deficiency. Endocr Rev 30, 376-408.

19. Andersson M, Thankachan P, Muthayya S et al. (2008) Dual fortification of salt with iodine and iron: a randomized, double- blind, controlled trial of micronized ferric pyrophosphate and encapsulated ferrous fumarate in southern India. Am J Clin Nutr 88, 1378-1387.

20. Assey VD, Peterson S, Kimboka S et al. (2009) Tanzania national survey on iodine deficiency: impact after twelve years of salt iodation. BMC Public Health 9, 319.
21. Wegmuller R, Camara F, Zimmermann MB et al. (2006) Salt dual-fortified with iodine and micronized ground ferric pyrophosphate affects iron status but not hemoglobin in children in Cote d'Ivoire. J Nutr 136, 1814-1820.

22. Zimmermann MB, Wegmuller R, Zeder C et al. (2004) Dual fortification of salt with iodine and micronized ferric pyrophosphate: a randomized, double-blind, controlled trial. Am J Clin Nutr 80, 952-959.

23. Zimmermann MB, Zeder C, Chaouki N et al. (2003) Dual fortification of salt with iodine and microencapsulated iron: a randomized, double-blind, controlled trial in Moroccan schoolchildren. Am J Clin Nutr 77, 425-432.

24. Haas JD, Rahn M, Venkatramanan S et al. (2014) Doublefortified salt is efficacious in improving indicators of iron deficiency in female Indian tea pickers. $J$ Nutr 144, 957-964.

25. Habicht J-P \& Pelto GH (2011) Multiple micronutrient interventions are efficacious, but research on adequacy, plausibility, and implementation needs attention. J Nutr 142, issue 1, 205S-209S.

26. Habicht J-P \& Martorell R (2010) Probability, plausibility, and adequacy evaluations of the Oriente Study demonstrate that supplementation improved child growth. J Nutr 140, 407-410.

27. Habicht J-P, Victora CG \& Vaughan JP (1999) Evaluation designs for adequacy, plausibility and probability of public health programme performance and impact. Int J Epidemiol 28, 10-18.

28. Burger SE, Haas JD \& Habicht J-P (1993) Testing the effects of nutrient deficiencies on behavioral performance. Am J Clin Nutr 57, 1-8.

29. Victora CG, Habicht J-P \& Bryce J (2004) Evidence-based public health: moving beyond randomized trials. $\mathrm{Am} \mathrm{J}$ Public Health 94, 400-405.

30. Habicht J-P \& Frongillo EA (2005) Discussion: targeting is making trade-offs. J Nutr 135, 894-897.

31. Cook JD, Flowers CH \& Skikne BS (2003) The quantitative assessment of body iron. Blood 101, 3359-3363.

32. Thurnham DI, McCabe LD, Haldar S et al. (2010) Adjusting plasma ferritin concentrations to remove the effects of subclinical inflammation in the assessment of iron deficiency: a meta-analysis. Am J Clin Nutr $92,546-555$.

33. Hochberg Y (1988) A sharper Bonferroni procedure for multiple tests of significance. Biometrika 75, 800-802.

34. Raiten DJ, Namasté S, Brabin B et al. (2011) Executive summary - Biomarkers of Nutrition for Development: Building a Consensus. Am J Clin Nutr 94, issue 2, 633S-650S.

35. Borel MJ, Smith SM, Derr J et al. (1991) Day-to-day variation in iron-status indices in healthy men and women. Am J Clin Nutr 54, 729-735.

36. World Health Organization \& Centers for Disease Control and Prevention (2007) Assessing the Iron Status of Populations: Including Literature Reviews. Report of a Joint World Health Organization/Centers for Disease Control and Prevention Technical Consultation on the Assessment of Iron Status at the Population Level, Geneva, Switzerland, 6-8 April 2004, 2nd ed. Geneva: WHO.

37. Petry N, Olofin I, Hurrell RF et al. (2016) The proportion of anemia associated with iron deficiency in low, medium, and high human development index countries: a systematic analysis of national surveys. Nutrients $\mathbf{8}, 693$.

38. Hodges JL \& Lehmann EL (1963) Estimates of location based on rank tests. Ann Math Stat 34, 598-611.

39. Gibson RS (2005) Assessment of folate and vitamin B12 status. In Principles of Nutritional Assessment, p. 595. New York: Oxford University Press.

40. Low MSY, Speedy J, Styles CE et al. (2016) Daily iron supplementation for improving anaemia, iron status and health in menstruating women. Cochrane Database Syst Rev issue 4, CD009747. 
41. Wu T, Liu GJ, Li P et al. (2002) Iodised salt for preventing iodine deficiency disorders. Cochrane Database Syst Rev issue 3, CD003204.

42. Fairchild MW, Haas JD \& Habicht J-P (1989) Iron deficiency and behavior: criteria for testing causality. Am J Clin Nutr $\mathbf{5 0}$ 566-574.

43. Asibey-Berko E, Zlotkin S, Yeung G et al. (2007) Dual fortification of salt with iron and iodine in rural Ghana. East Afr Med J 84, 473-480.
44. Rajagopalan S \& Vinodkumar M (2000) Effects of salt fortified with iron and iodine on the haemoglobin levels and productivity of tea pickers. Food Nutr Bull 21, 323-329.

45. Suchdev PS, Williams AM, Mei Z et al. (2017) Assessment of iron status in settings of inflammation: challenges and potential approaches. Am J Clin Nutr 106, Suppl. 6, 1626S-1633S.

46. Latunde-Dada GO (2000) Women and sustainable approaches to the management of iron deficiency. Food Nutr Bull 21, 275-281. 